\title{
Elements of Czech and Moravian Folklore in the Production of Bohuslav Martinů and His Pupil Jan Novák
}

\author{
Martin Flašar
}

\section{Introduction}

The present paper is based on a few presumptions. They are centred on a conflict of traditional and new folklore in 1950s and 1960s under the Communist rule in Czechoslovakia.

In these decades folk music became a means of justification and affirmation of the new social order based on so called "working class". The situation was as follows: signs of traditional folklore widely understood as an authentic expression of folk culture were adapted and implanted into a new social order. Having undergone a slight transformation they were meant to function as a means of creating new authenticity, new status of social identification of class-consciousness.

Underlying this process were two conflicting layers of folklore: the newly constructed "new folklore" with the naturally inherent "old or traditional folklore".

Paradoxically, contemporary interpretation of this period is susceptible to a rather distorted nostalgic portrayal of this period, as a golden era of folklore in $20^{\text {th }}$ century regardless of its political causes and consequences.

\section{Traditional versus New Folklore. Situation in Bohemia and Moravia in mid 1950s}

The cultural atmosphere of the early fifties was defined by cultural policy of the Central Committee of the Union of Czechoslovak Composers, which was modelled on its Soviet counterpart as an extension of the Communist Party of Czechoslovakia.

Ideologically, the Union was based on the principles of socialist realism and critique of formalism. This designation had been used as a negative value judgment concerning uncomfortable composers and authors, both in the Soviet Union and in the Czech 
Republic. Recommended genres of socialist realism were mass songs and cantatas, which were capable of carrying ideological messages and at the same time they were expected to provide broad masses of recipients with a decent artistic standard.

In 1952 the Brno Radio Orchestra of Folk Instruments was established in a context of massive wave of "new folklore", which in its intensity could be compared to the folkloristic fever at the end of the $19^{\text {th }}$ century. Czechoslovak radio fostered close contacts between composers and folk musicians from the country, who were presented as an authentic model. Czechoslovak Radio Brno had functioned as a melting pot mixing elements of folk and artificial music.

The main distinctive features of the new folklore were:

1. Maximal simplification of musical structure based on tonality with modal elements, with melody and rhythm abstracted from the folk songs and dance music.

2. Binding of music to text, which is capable of carrying any message or content thereby using a metaphorical language, typical of folk songs, but drawing attention to the current problems of working-class life. Commonly used was a moral lesson at the end of the songs. It concerned widely applied symbols (red colour, factories, sickles and hammers etc.). Another important feature was using an epic and strophical text.

3. Popular topics revolved around common everyday life - favourite heroes in the mass songs became workers, miners, pilots, athletes, soldiers, drivers, train conductors, farmers, etc. Typical of them were compulsory positive values such as a joy of life, love of their country, working objectives, social class consciousness and above all: love of their job.

\section{The Opening of the Wells. Bohuslav Martinů and Folklore as a Reconciliation Act}

Besides the compulsory production of new folklore we can trace a long tradition of natural folklore influences on the Czech and Moravian artificial music. This tradition can be traced back to $19^{\text {th }}$ century composers living in Brno such as Pavel Křižkovský, his pupil Leoš Janáček and his followers in $20^{\text {th }}$ century: Pavel Haas, Jan Kunc, Vitězslava Kaprálová, Jan Novák etc. The main representative of the folklore reception Vítězslav Novák worked in Prague. It was by strange coincidence that Bohuslav Martinů did not study with him but with Josef Suk, bearer of Antonín Dvořák's musical tradition.

Regarding the application of elements of folk music and culture in the works of Bohuslav Martinů, we must mention several areas. They are especially folk songs and dances, aesthetics of a folk theatre, medieval mysteries, Italian comedia dell'arte or folk rhymes. Martinů - loyal to the tradition of Smetana - applies polka in several cycles. Later, he returns to polka in Paris and in the U.S. in the Three Czech Dances, piano cycle Borová, in Špalíček or in Etudes and polkas. 
An important chapter in the work of B. Martinů are pastoral motifs. ${ }^{19}$ Pastorale is considered as one of the typical features of Martinů works. Designation "pastorale" appears as the title of songs or movements in five compositions: in the piano Fairy tale of Goldilocks (1910), Pastorales pour violoncello et piano (1930), in the second movement of the Concerto for Violin and Orchestra No. 1 (1933), Stowe pastorals (Nonet for 5 flutes, clarinet and two violins), in opera What do people live by subtitled Pastoral Opera in 1 Act (1951-1952) and Parables for large orchestra (1957-1958). An important feature of lyrical pastorale in Martinů is $6 / 8$ measure (or $9 / 8$ or 12/8), moderate movement, metric regularity broken by ligatures and interval parallelism (third, sixth), the prevalence of major tonalities (in Martinů usually B flat major ). These features could be found for example in the orchestral cantata Bouquet of Flowers (1937), in the first movement of the First symphony, in the Piano quartet, in Pastorale from the piano cycle Etudes and polkas (1945). Also the Second symphony is marked as "Pastoral".

Inspiration by Czech and Moravian folklore appeared in Martinůss works in 1930s. There are at least three main reasons:

a) living in Paris for a decade strengthens in Martinů feelings of necessity to return to the roots of his own culture, folklore of Moravian countryside,

b) composer slowly approaches his forties, experiments in civilism and his avant-garde tendencies are gone and he is striving for lasting values,

c) growing danger of Nazism reminds the composer of the importance of humanism inherent in the Czech cultural tradition.

Idioms of Czech folklore are evident in the ballet The Chap-Book (1931), opera cycle The Plays of Mary (premiered in 1935 in Brno), whose primitivism was criticized by the founder of Musicology at Masaryk University Vladimír Helfert in his seminal book Czech modern music (1937), Theatre Behind the Gate (1936) or Bouquet of Flowers (1937). The highlights of Martinu's reflection of the folk culture is a tetralogy of cantatas as analogy to the Four Seasons: The Opening of the Wells, Romance of the Dandelions, Legend of the Smoke from Potato Fires, Mikeš from the Mountains.

Bohuslav Martinů became, as well as subsequently Jan Novák, immigrant due to external circumstances. His leaving of Paris in 1923 was motivated solely by study intentions with Albert Roussel, who fulfilled his desire for a new sound coming from impressionism. In February 1948, the Communist Party of Czechoslovakia took over the power in the country and the official garniture declared Martinu to be a cosmopolitan - and therefore undesirable - composer. This designation was de facto equal to the liquidation of his name and work in the post-February Czechoslovakia.

As an example of the sudden change of political situation could be official rating of Martinů's Field Mass (1939) setting lyrics by Jiři Mucha. One of the future leaders of

19 Well-researched study on this topic is by Jan Trojan in the sixth issue of Opus Musicum 2004, pp. 6-12. 
the Union of Czechoslovak composers Antonín Sychra wrote about it to be an excellent work which does not strive for exclusivity and experimentation and has all preconditions to become popular. Four years later the same critic wrote that Field Mass with its quaint instrumentation is targeted at the Western bourgeois audience, does not express a martial enthusiasm and optimism of the people, just a bleak homesickness. ${ }^{20}$

Forced shutdown had ended up with the already mentioned cantata The Opening of the Wells in 1956, which allowed him to step in through the door of folk music onto our music scene and started slowly a long period of considerably distorted reception of his work in Czechoslovakia. The Opening of the Wells is a cantata based on the text by poet Miloslav Bureš, inspired by traditional folk custom kept in the Czech-Moravian Highlands, which is based on cleaning natural springs by children accompanied by songs, dances and improvisational theatrical events.

The main distinctive features of this cantata are: simplicity, folk subject and folk-like poetry with its metaphorical language.

\section{Adaptation of a Passion Play. Jan Novák and Traditional Folklore as a Cultural-Political Subversion?}

Jan Novák, a Moravian composer born in 1921, shared his teacher's fate. Studying with Martinů in New York he returned to Czechoslovakia in the unfortunate February 1948. In the following 20 years he struggled with Composers Union and in 1968, after the invasion of Warsaw Pact armies to Czechoslovakia he emigrated with his family to Aarhus in Denmark, later to Italy and Germany, where he died in 1984. Although based primarily on Latin, his work had never lost its roots in Moravian folk tradition of natural musicianship.

Folk culture in Novák's production is presented on two main levels:

Firstly, on the level of the subject matter. It was for example the ballet Specter's Bride (1954) based on the theme of folk ballad included in the important collection of folk poetry written by Karel Jaromír Erben in $19^{\text {th }}$ century. Furthermore it was a Comedy about the Passion and Resurrection of our Lord and Saviour Jesus Christ (1965) based on the libretto by Czech puppeteer Jan Kopecký, which draws on folk tradition of mystery plays. In this music play Jan Novák approached Bohuslav Martinů model at most.

History of this passion play goes back to German Capuchin priest Martin von Cochem (Martin Linius), who published in 1681 a book Leben und Leiden unseres Herrn Jesu Christi und seiner glorwürdigsten Mutter Maria which became soon very popular also in translation into Czech. ${ }^{21}$ Inspired by Cochem was also a book of spiritual visions by

20 Jaroslav Mihule, Martinů: osud skladatele (Praha, 2002), p. 432.

${ }^{21}$ Vojtěch Ron, Lidové pašijové divadlo v českých zemích (Praha, 2009), p. 60. 
Anna Katherina Emmerick written down by famous poet Clemens Brentano under the title The Dolorous Passion of Our Lord Jesus Christ (1833).

Very typical of Czech milieu of $19^{\text {th }}$ century were "passion plays" performed by amateur actors. Probably the most representative centre of this genre was in Hořice in Southwest Bohemia. The tradition of passion plays was founded there in 1893. This phenomenon also functioned as a tool for testing ruling ideologies. Both Nazism in 1940s and Communism in 1950s and 1960s resolutely banned performances of these folk plays. From this point of view Jan Novák's setting of the Passion in middle 1960s was quite an act of bravery.

It is possible to state that in 1960s there was a strong reflection of folk plays in Czech theatre. In Brno there can be found several inspirations by folk puppet plays in composers like Josef Berg or Jan Novák.

Secondly, in terms of specific idioms it could be the dance polka, which occurs as the sixth variation of the Variations on a Theme by Bohuslav Martinů. Martinů likewise returns to the roots of his culture when being in exile, apparently from a certain sense of nostalgia or uprootedness. It is a well-known fact that while in exile he had a collections of folk songs by Sušil and Janáček sent to him. In the mid-fifties originate song cycle Magical songs based on folk poetry with accompaniment of a flute and drum (1955). Two piano cycles Rustica Musa (1973 and 1975) represents setting of Moravian folk songs.

Similarly to Martinů Novák applies pastorale in the second movement of the Concerto for piano and small orchestra completed under the supervision of his teacher.

\section{Conclusions. The Traditional as the New. Folk Passion Play as a Contemporary Avant- -garde. Question of Norms and Values}

When comparing the two approaches to music folklore in 1950s in Czechoslovakia there can be clearly seen following differences:

\begin{tabular}{|l|l|}
\hline Traditional folklore & New folklore \\
\hline - natural popular piety & - indoctrinated faith in the human potential \\
- spiritual verticality & - levelling horizontality \\
- understanding of the human weaknesses, & - compulsory happiness and optimism \\
spontaneity & - simple, artificial and historizing music \\
- music structure derived from contemporary & structure \\
high music culture & - means of artificial construction of social \\
$\begin{array}{l}\text { expression of the social and cultural identi- } \\
\text { fication }\end{array}$ & status and class-consciousness \\
- natural need of creation & \\
\hline
\end{tabular}

On one hand, 1950s witness flourishing of composers prolifically churning out mass songs singing about pilots, drivers, miners, workers and soldiers performed by politically 
established institutions. On the other hand, this tendency is countered by a few composers developing the tradition of humanism as a guarantee of stability of cultural values. Bohuslav Martinů and his pupil Jan Novák were one of them.

This paper has been presented at the international conference Semiotics of Cultural Heritage - Remembering, Restoring, Renewing, ISI Summer School in Imatra, Finland, 10. 6. 2013.

\section{Bibliography}

1. Martin Flašar, "Jan Novák, žák Bohuslava Martinůu, Hudební věda, 43 (2006), p. 59-74.

2. Jaroslav Mihule, Martinů: osud skladatele (Praha, 2002).

3. Vojtěch Ron, Lidové pašijové divadlo v českých zemích (Praha, 2009).

4. Jan Trojan, "Pastorale v dile Bohuslava Martinü", Opus musicum, 36 (2004), p. 6-12.

5. Andrej A. Ždanov, O umění (Praha, 1950).

\section{Prvky českého a moravského folkloru v tvorbě Bohuslava Martinů a jeho žáka Jana Nováka}

\section{Shrnutí}

Předmětem předkládané studie je konfrontace nového a tradičního folkloru v 50. a 60. letech 20 . století. V tomto období dochází k paradoxní situaci, kdy tradiční hodnoty začnou být náhle vnímány jako něco podvratného a potenciálně nebezpečného, ačkoliv teze socialistického realismu zdánlivě proklamují jejich modelovou roli. Funkci sond vnořených do aktuální proměny hodnotové zde hrají osobnosti Bohuslava Martinů a jeho žáka Jana Nováka. Právě na jejich tvorbě se ukazuji proměny hodnotových soudů a celkové rétoriky v závislosti na změně společenského klimatu v Československu po roce 1948. Účelem této studie je mimo jiné přispět $k$ dekonstrukci obecně rozšiřeného mýtu o „zlaté éře“ folkloru v 50. letech poukázáním na jeho politické pozadí a vtělenou komunistickou propagandu. Výsledkem zkoumání výše zmíněných fenoménů je přehledný výčet a komparace distinktivních rysů tradičního a nového folkloru. 


\title{
Elemente der böhmischen und mährischen Folklore in der Produktion von Bohuslav Martinů und seinem Schüler Jan Novák
}

\begin{abstract}
Zusammenfassung
Zahlreiche loci communes können in der Produktion von tschechischen Komponisten Bohuslav Martinů (1890-1959) und seine einzige tschechische Schüler Jan Novák (1921 - 1984) gefunden werden. Es ist insbesondere ihr Interesse an der tschechischen und mährischen Volkslieder und Tänze, Ästhetik des Volkstheaters, mittelalterliche Passionsspiele, commedia dell'arte, pastoralen Motiven und Folk Reime. Für beide Komponisten war die Wahl dieser Elemente ganz natürlich, die sich aus ihrer kulturellen Wurzeln aufwuchs. Ihre Rückkehr auf die Frage der Volkskultur in der Nachkriegs-Entwicklung stellt eine Opposition gegen die offizielle Kulturpolitik des tschechoslowakischen Staates basiert am sozialistischen Realismus, der die Herstellung einer „neuen Folklore“, entsprechend den Bedürfnissen der „Arbeiterklasse“, durchsetzte. Die Erneuerung der Alten in Opposition zur Schaffung der Neuen bildet den Rahmen dieser Arbeit. Die ganze Debatte konzentriert sich auf widersprüchliche Probleme von Werten und Normen verbunden mit der wandelnden Gesellschaft.
\end{abstract}

\section{Klíčová slova}

Folklór; kulturní politika; Československo; socialistický realismus; Jan Novák; Bohuslav Martinů.

\section{Key words}

Folklore; culture policy; Czechoslovakia; socialist realism; Jan Novák; Bohuslav Martinů. 